Annals of Plant Sciences

\title{
Taxonomic description and annotation of Poa albertii Regel (Poaceae: Pooideae, Poeae, Poinae) from North Western Himalayas, India.
}

Mudassir Ahmad Bhat ${ }^{1}$, Sheikh Abdul Shakoor ${ }^{1,2}$ and Amarjit Singh Soodan ${ }^{1 *}$

${ }^{1}$ Systematics and Biodiversity Laboratory, Department of Botanical and Environmental Sciences, Guru Nanak Dev University, Amritsar, Punjab-143005, India.

2Department of Botany, Govt. Degree College, Kulgam (J \& K) - 192231, India.

Received: 1/27/2018; Accepted: 2/19/2018

\begin{abstract}
Poa albertii Regel, a native to Central Asia, has been described from North-Western Himalayan region and annotated to the latest system of grass classification. A detailed taxonomic description in the latest format, along with illustrations and Scanning Electron Micrograph of diagnostic features is provided to diagnose P. albertii Regel from allied species.
\end{abstract}

Keywords: Grasses, Poa, Himalayas, Taxonomy.

\section{Introduction}

Poa L. Salkimotu Cabi and Dogan, 2012) is the type genus of the grass family Poaceae Barnhart. The genus includes more than 550 species distributed worldwide (Gillespie and Soreng, 2005). A majority of species occur in temperate to alpine regions. Species identification in the genus is rendered difficult by the existence of polymorphism and high incidence of polyploidy, apomixis and hybridization (Stebbins, 1950; Clausen, 1961; Tzvelev, 1983; Hunziker and Stebbins, 1987; Kavousi et al., 2015). Clayton and Renvoize (1986) concluded that Poa was an extremely uniform genus for which infrageneric classification was difficult to achieve. The affinities of nearly half of the species are unknown while rest of the species has been put in informal groups (Soreng et al., 2009).

Despite difficulties mentioned in the preceding part, Poa has attracted the attention of several agrostologists including Bor (1970) who reported 13 species of the genus from Iran. Other reports include Cope (1982) from Pakistan (33), Chen et al., (2006) from China (156), Press et al., (2000) from Nepal (32), Noltie (2000) from Bhutan including some parts of Sikkim and Darjeeling (29) with the species number given in the parenthesis. More recently, Soreng and Peterson (2012), provided a revisionary account of the genus from Mexico with new reports resulting from latest delimitation of species within the genus.

Despite wide distribution in the Himalayas, taxonomic works in the genus have been marked by unusually long intermissions. Stapf (1896) studied the genus for Hooker's 'Flora of British India'

\footnotetext{
*Corresponding Author:

Mudassir Ahmad Bhat,

Department of Botanical \& Environmental Sciences,

Guru Nanak Dev University,

Amritsar (Punjab)-143005, India.

E-mail: assoodan@gmail.com
}

followed by Duthie (1883, 1906), Bor (1941, 1960), Stewart (1945), Raizada et al., (1983), Babu (1977) and Naithani (1985). Rajbhandari (1991) published a taxonomic monograph of the genus Poa from the Himalayan region. The author included fifty two species with a key for their identification. Recently, Nautiyal and Gaur (2017) reported 45 species (and 2 subspecies) of the genus Poa spp. from Uttarakhand (India) with a key based on morphological characters. Olonova, et al (2017) has scrutinized the dwarf species of Poa section Stenopoa of the Himalayan region and demarcated ten species of which Poa attenuata Trin., Poa glauca Vahl and Poa. albertii Regel were put in a closely related group within the section.

The present paper validates P. albertii Regel through detailed taxonomic description supported by illustrations of diagnostic parts and a key to taxonomic demarcation.

\section{Materials and Methods}

Occurrence and Type Location: The species is common in alpine grazing meadows $(3000-5200 \mathrm{~m}$ asl.) of the north-western Himalayan region. The species was collected from Nyoma (district Leh) in the cold desert of Ladakh. The site of collection is located at $33^{\circ} 12^{\prime} 197^{\prime \prime} \mathrm{N}$ to $78^{\circ} 39^{\prime} 243^{\prime \prime} \mathrm{E}$ at an elevation of $4203 \mathrm{~m}$ asl and experiences a cold temperate climate. The species was collected on July 4, 2014 (Fig. 1) during explorations of the northwestern Himalayan region for diversity of grasses. Herbarium sheets of preserved specimens have been deposited in the Herbarium of the Department of Botanical \& Environmental 
Sciences, Guru Nanak Dev University, Amritsar (voucher nos 7373 to 7375 ).

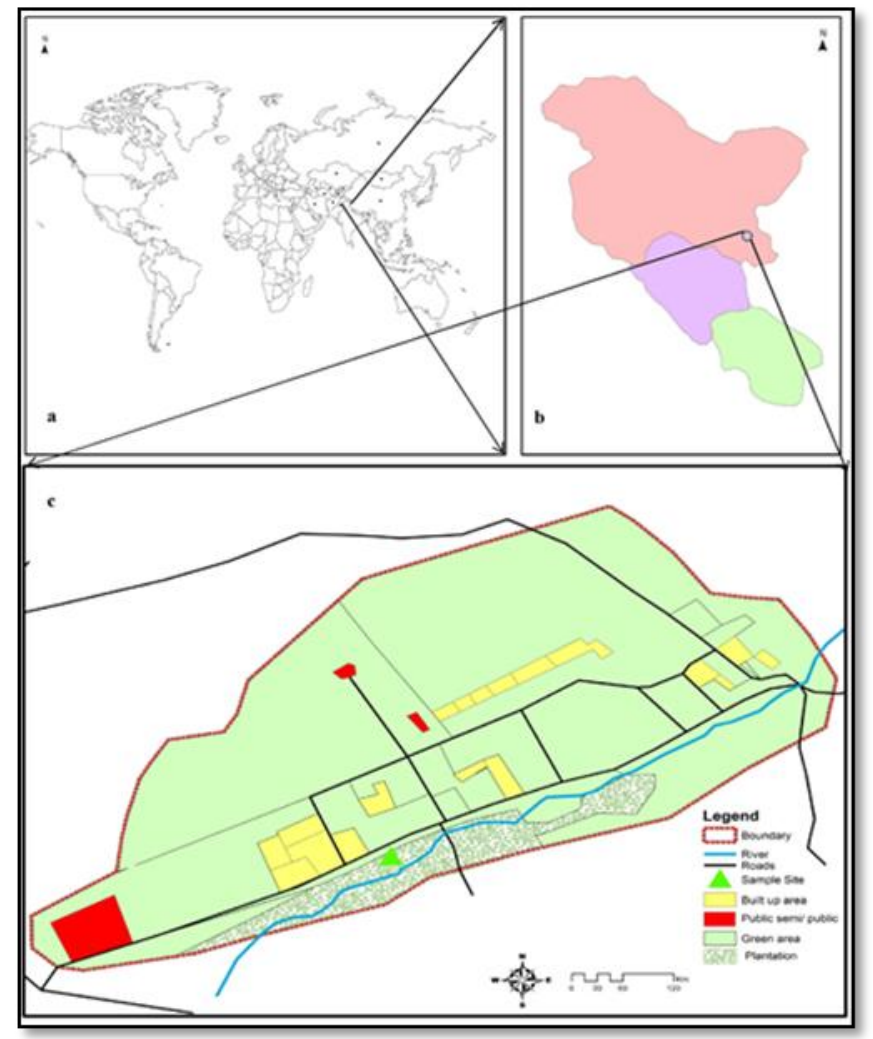

Fig. 1. a) Distribution of Poa albertii Regel b) North- Western Himalayan region c) Collection site of Poa albertii Regel.

Methodology: Stereoscopic examination of the specimens was followed by taxonomic description and identification with the help of taxonomic literature (Bor 1960) and online sources viz., efloras of China, Pakistan, and Online Grass Flora of the world. Illustrations were prepared manually by drawing the vegetative and floral parts, tracing and inking the drawings followed by scanning with HP Scanjet G3110 scanner. Information on the distribution in temperate and tropical Asia has been included to indicate the places and areas that show a sizeable occurrence of the species (e-flora of China). Spikelet formula has been written in the format proposed by Allred and Columbus (1988) with some modifications. The spikelet diagram has been prepared in the software (Adobe Photoshop 7.0) by employing symbols improvised from time to time (Schaffner 1916, Arber 1934, Singh 1999, Subrahmanyam 2004, Craene 2010, Kumar 2014). In the diagram, lateral compression of the spikelets has been shown by drawing wedge shaped glumes followed by fertile florets indicated by horizontal solid lines and dashed lines represent reduced florets. Essential whorls have been indicated by three anthers with a unilocular ovary in the centre. A bifid style is also indicated. Surface features of caryopses were visualised and imaged through stereoscopic examination and Scanning Electron Microscopy (ZEISS-EVO LS10) operated at an accelerating voltage of $15 \mathrm{kv}$ at appropriate magnifications.

\section{Taxonomic account}

Etymology: The generic name is a direct adoption of the feminine Greek noun, 'poa $(\pi \dot{o} \alpha)=$ grass, fodder'. With no change of spelling, generic name ' Poa' is treated as a feminine noun even after adaption as a generic name because it has an established gender in the source language. Specific epithet is commemorative of the Swiss botanist, Albert Regel. The first name of the author has been put in the genitive case of a Latin noun employing the inflectional termination ' $i$ ' of the genitive case. As specific epithet commemorates a gentleman (not a woman), it is treated as a masculine epithet which, consequently, does not show gender accord with the feminine generic name.

Synonyms: Poa albertii var. triflora Regel Gamayunova, A. P. 1956. Poa. 1: 221-238. In Fl. Kazakstana. Poa crymophila Keng Tzvelev, N. N. 2001. Poa IN: Pl. Cent. Asia 4: 156-177. Poa roshevitzii Golosk. Filatova, N. S. 1969. Poa. 92-97. In N. S. Filatova Ill. Oprd. Rast. Kazakh. Poa mustangensis K.R. Rajbhandari, 1880. Act. Hort. Petrop. 7: 611. Poa arnoldii A. Melderis, 1978. Enum. Fl. Pl. Nepal, 1: 142. Poa rangkulensis Ovchinnikov \& 
Chukavina, lzvest. 1956. Otdel. Estestven. Nauk Akad. Nauk Tadzhik. SSR. 17: 41.

Taxonomic description: Perennial; Culm erect, 10-30 cm long. (Fig. 2a) Leaf blades $2.0-5.0 \mathrm{~cm}$ long, 1.0-1.5 mm wide. Ligule membranous, 1.5-2.0 $\mathrm{mm}$ long (Fig.2b). Inflorescence an open panicle, 4$8 \mathrm{~cm}$ long. Spikelets solitary, tinged with purple, 2-3 floreted, pedicelled, laterally compressed, 4.0-5.0 $\mathrm{mm}$ long (Fig. 2c). Disarticulation of spikelets above the glumes. Glumes unequal, (Fig.2d) lower glume lanceolate, 2.5-3.5 mm long, 1 keeled, 3 veined, apex acute (Fig. 2e). Upper glume, 3.0- 4.0 $\mathrm{mm}$ long, 1 keeled, 3 veined, 1.1-1.2 length of lower glume, 0.9-1.0 length of the fertile lemma (Fig.2f). Fertile lemma lanceolate, $3.0-4.5 \mathrm{~mm}$ long, lemma bigger than the glumes, 5 veined, keel shortly pubescent for half of its length, marginal veins for one third, other parts glabrous (Fig. 2g). Palea shorter than the lemma, keels scabrid (Fig. 2h). Lodicules 2, anthers 3, 1.2-1.5 mm long, stigmas 2. (Fig. 2i). A single fertile floret (enclosing the caryopsis) with rachilla segment and occasionally by a reduced floret as well is the dispersal unit (the diaspore). The diaspore is light yellow to purple in colour (Fig. 2 j-l). Caryopsis 1.0-1.5 mm long, reddish-brown, adherent pericarp, ovate to obovate with a slight lateral compression, hilum punctiform, stylopodium present(Fig. $2 \mathrm{~m}-\mathrm{n}$ ), surface reticulate with undulating striations (Fig. 2o-r). Common, in alpine grazing meadows, between 3000-5200 m elevation.

Flowering \& Fruiting: June-September

Asia-Temperate: China; China North-Central, China South-Central, Inner Mongolia, Tibet, Xinjiang, Qinghai. Middle Asia; Kirgizistan, Tadzhikistan, Kazakhstan, Uzbekistan. Mongolia; Mongolia. Russia, Iran West Asia; Afghanistan.

Asia-Tropical: Indian Subcontinent; Eastern Himalaya, Nepal, Pakistan.

\section{Spikelet formula:}

$\mathbf{R}^{1}$ : Reduced floret 1

$\mathbf{F}_{5}$ : 2-3 fertile florets, lemma 5 veined

--- : Disarticulation above the glumes

$\mathbf{G}_{3}$ : Lower glume 3 veined

$\mathbf{G}_{3}$ : Upper glume 3 veined

Pan: Inflorescence, a panicle

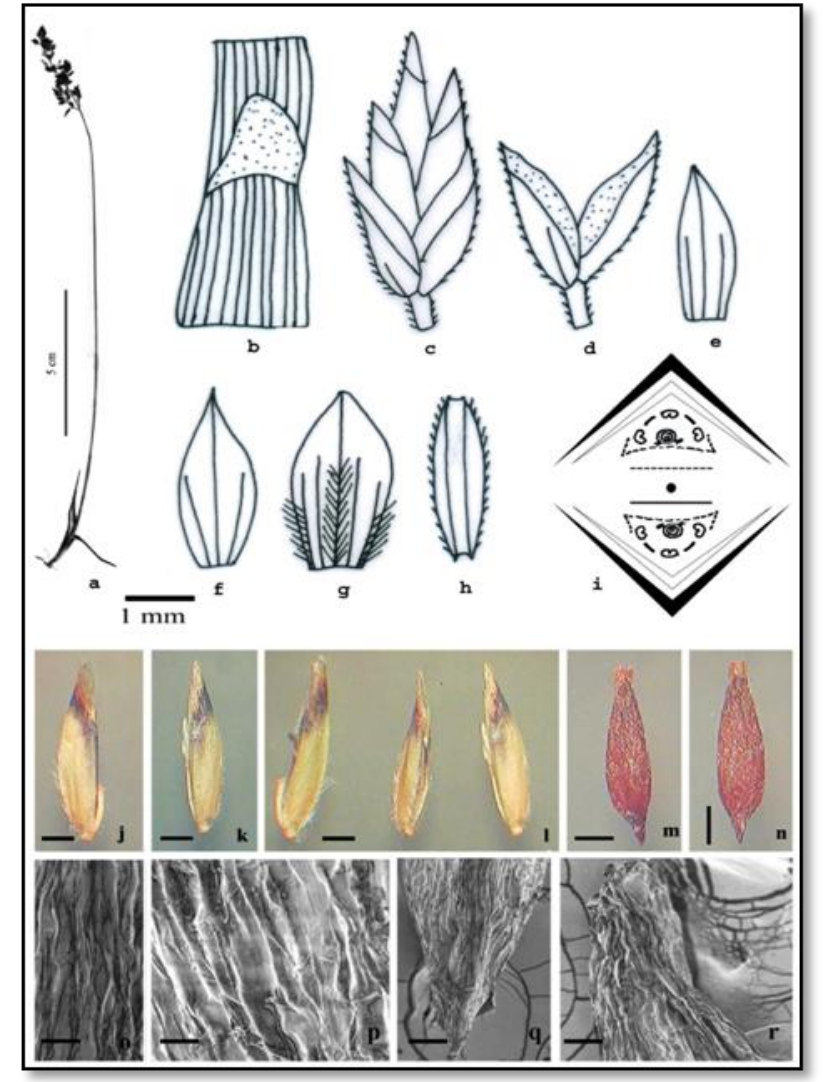

Fig. 2. Poa albertii: a) habit; b) ligule; c) spikelet; d) glumes; e) lower glume, dorsal view; f) upper glume, dorsal view; g) lemma, dorsal view; h) palea; I) spikelet diagram; j-l) diaspore; mn) caryopsis; o-r) SEM Micrographs of caryopsis [Bar: $5 \mathrm{~cm}$ (a) $1 \mathrm{~mm}$ (b-h) $0.7 \mathrm{~mm}$ (j-l) $0.3 \mathrm{~mm}$ (m-n) $50 \mu \mathrm{m}(\mathrm{o}-\mathrm{p}) 300 \mu \mathrm{m}(\mathrm{q}-\mathrm{r})]$ 
Table 1. Diagnosis of Poa albertii Regel from related species

\begin{tabular}{lccccc}
\hline \multicolumn{1}{c}{ Species } & $\begin{array}{c}\text { Ligule length } \\
\text { (mm) }\end{array}$ & $\begin{array}{c}\text { Spikelet length } \\
\text { (mm) }\end{array}$ & $\begin{array}{c}\text { Number of fertile } \\
\text { florets }\end{array}$ & \multicolumn{2}{c}{$\begin{array}{c}\text { Callus surface } \\
\text { veins }\end{array}$} \\
\hline Poa albertii Regel & $1.0-3.5$ & $3.0-6.0$ & $2-3$ & Glabrous & Glabrous \\
Poa attenuata Trin. & $1.0-2.5$ & $2.5-4.5$ & $2-5$ & Webbed & Moderatly pubescent \\
Poa glauca Vahl & $1.0-2.0$ & $3.8-7.0$ & $2-4$ & Glabrous or webbed & Glabrous or pubescent \\
Poa koelzii Bor & $1.0-3.0$ & $4.0-6.0$ & $2-5$ & Glabrous & Densely pubescent \\
Poa labulensis Bor & $2.0-4.0$ & $5.0-7.2$ & $2-4$ & Glabrous or sometimes hairy & Sparsely pubescent \\
\hline
\end{tabular}

Identification key:

1. Plants densely tufted .......................Poa attenuata

1b. Plants tufted moderately .....................

2a. Lemma glabrous between the veins...........Poa albertii

2b. Lemma pubescent between the veins...........3

3a. Callus glabrous or webbed......................... gluaca

3b. Callus usually glabrous ........... 4

4a. Ligule 1-3 mm long ....................Poa koelzii

4b. Ligule 2-4 mm long...................Poa labulensis

\section{Acknowledgements}

The authors grateful to Professor Incharge Emerging Life Sciences Laboratory, Guru Nanak Dev University, Amritsar, Punjab (India) for Scanning Electron Microscopy (SEM) The help received from Mr. Musaib Ahmad Wani (Guru Ram Das School of Planning, GNDU, Amritsar) in designing the map of the study area is gratefully acknowledged. The first author is thankful to the University Grant Commission, New Delhi for financial assistance under Major Research Project (MRP) fellowship.

\section{References}

1. Allred, K, and Columbus, J.T. "The grass spikelet formula: an aid in teaching and identification. Journal of Range Management 41. (1988): 350-351. Print.

2. Arber, A. "The gramineae: a study of cereal, bamboo and grass". Cambridge University Press. (1934). Print.

3. Babu, C.R. "Herbaceous Flora of Debradun" Council of Scientific and Industrial Reaserch (CSIR), New Delhi. (1977). Print.

4. Bor, N.L. "Some Common U.P. Grasses". Indian For. Rec. n.s. Bot. 2. (1941):1-220. Print.

5. Bor, N.L."The Grasses of Burma, Ceylon, India and Pakistan (Excluding Bambuseae)" Pergamon Press. (1960). Print.

6. Bor, N.L. "Poa L. In: Rechinger K.H. (ed.), Flora Iranica" Graz, Austria: Akademische Druck - u Verlagsanstalt. 70. (1970): 20-46. Print.

7. Cabi E, Doğan M "Poaceae. In Güner A, Aslan S, Ekim T, Vural M, Babaç MT, editors. Türkiye Bitkileri Listesi (Damarlı Bitkiler)". İstanbul, Turkey: Nezahat Gökyiğit Botanik Bahçesi ve Flora Araştırmaları Derneği Yayını. (2012): 690- 756. Print.

8. Chen S. et al., Poa L. In: www.eFloras.org Flora of China. Published on the Internet. (2006):

http://www.efloras.org/flora_page.aspx?flora_id =2 /accessed on 28.07. 2017.
9. Clausen J, Introgression facilitated by apomixis in polyploidy Poas. Euphytica 10. (1961): 87-94. Print.

10. Clayton, W.D, and Renvoize, S.A. "Genera Graminum: Grasses of the World". London, UK. Kew Bull. 13. (1986): 1-389. Print.

11. Clayton, W.D., Vorontsova, M.S., Harman KT, Williamson H, "Grass Base - The Online World Grass Flora". 2006: http://www.kew.org/data/grasses-db.html/ accessed on 28.07. 2017.

12. Cope, T.A. "Poa L. In: www.eFloras.org Flora of Pakistan. Herbarium Royal Botanic Garden, Kew. Published on the Internet (1982): http://www.efloras.org/flora_page.aspx?flora_id=5 /accessed on 28.07. 2017.

13. Craene, L.P.R.D. "Floral diagrams: an aid to understanding flower morphology and evolution". The Edinburg Building, Cambridge CB2 8RU, Cambridge University Press, UK. (2010). Print.

14. Duthie, J.F. " $A$ list of the grasses of North-western India. Indigenous and cultivated". Roorkee, (1883). Print.

15. Duthie, J.F. "Catalogue of the Plants of Kumaon and of the Adjacent Portions of Garbwal and Tibet, based on the collections of Strachey and winter bottom during the years" London, (1906): 1846-1849. Print.

16. Gillespie, L.J., and Soreng, R.A. "Phylogenetic analysis of the bluegrass genus Poa based on cpDNA restriction site data". Syst. Bot. 30. (2005): 84-105. Print.

17. Hunziker, J.H., and Stebbins, G.L. "Chromosomal evolution in the Gramineae". In: Soderstrom, T.R. et al., (eds.), Grass Systematic and Evolution, Smithsonian Institution Press, Washington DC, USA. (1987): 179-187. Print.

18. Kavousi, M, Assadi, M, Nejadsattari, T. “Taxonomic revision of the genus Poa L. in Iran, new additions to Flora Iranica, and a new identification key". Turk. J. Bot. 39. (2015): 105-127. Print.

19. Kumar, A. "Exploration and Systematics of the grass flora of Punjab". Ph.D. Thesis, Guru Nanak Dev University. (2014). Print.

20. Naithani, B.D. "Poa L. Flora of Chamoll". Botanical Survey of India (BSI), Howrah, India. 2. (1985): 748-750. Print.

21. Noltie, H.J. "Flora of Bhutan: The Grasses of Bhutan". Royal Botanic Garden Edenburgh and Royal Government of Bhutan. 3. (2000): 549-572. Print. 
22. Nautiyal, D.C, and Gaur, R.D. "Poa L. species in Uttarakhand, India and keys for their identification". Taiwania. 62. (2017): 75-92. Print.

23. Olonova, M.V, Chen, Y, Miehe, S, Rajbhandri, K.R, and Barkworth, M. "Taxonomic notes on the dwarf bluegrasses (Poa L., Poaceae) of section Stenopoa in Pan-Himalayas". Taiwania. 62. (2017): 315-320. Print.

24. Press, J.R, Shrestha, K.K, and Sutton, D.A. "Poa L. In: www. Efloras. org. Annotated Checklist of the Flowering Plants of Nepal". Natural History Museum, London. Published on the Internet. 2000: http://www.efloras.org/flora_page.aspx?flora_id=1 10/accessed on 28.07. 2017.

25. Rajbhandari, K.R. "A Revision of the genus Poa L. (Gramineae) in the Himalaya". In: Ohba and Malla (eds.), The Himalayan Plants, University of Tokyo Press. 2. (1991): 169-261. Print.

26. Raizada, M.B, Jain, S.K, and Bahadur, K.N. "Grasses of the Upper Gangetic Plain Part III (Pooideae)". Jugal kishore and Co., Dehradun. (1983). Print.

27. Schaffner, J.H. "A general system of floral diagrams”. Obio J.Sci. 16.8. (1916): 360-366. Print.

28. Singh, G. "Plant systematics Theory and practice". Oxford and IBH Publishing Co. Pvt. Ltd., London. New Delhi. (1999). Print.

29. Soreng, R.J, Gillespie, L.J, and Jacobs, S.W.L. Saxipoa and Sylvipoa- two new genera and a new classification for Australian Poa (Poaceae: Poinae). Aust. Syst. Bot. 22.6. (2009): 401-412. Print.
30. Soreng, R.J, Peterson, P.M. "Revision of Poa L. (Poaceae, Pooideae, Poeae, Poinae) in Mexico: new records, re-evaluation of $P$. ruprecbtii, and two new species, P. palmeri and P. wendtii. PhytoKeys 15. (2012): 1-104. Print.

31. Stapf, O. "Poa. In: Hooker, J.D. (ed.) Flora of British India". L. Reeve and Co., London. 7. (1896): 337346. Print.

32. Stebbins, G.L. "Variation and Evolution in Plants". Columbia University Press, New York, USA, 1950. Print.

33. Stewart, R.R. "The Grasses of North-west India". Brittonia 5. (1945): 404-468. Print.

34. Subrahmanyam, N.S. "Modern plant taxonomy”. Vikas Publishing House Pvt. Ltd. New Delhi. 2004. Print

35. Tzvelev, N.N. Poa L. In: Tzvelev, (ed.), "Grasses of the Soviet Union", (translated from the Russian edition of 1976). Oxonian Press Pvt. Ltd., New Delhi. 1. (1983): 649-722. Print.

\section{Cite this article as:}

Mudassir Ahmad Bhat, Sheikh Abdul Shakoor and Amarjit Singh Soodan. Taxonomic description and annotation of Poa albertii Regel (Poaceae: Pooideae, Poeae, Poinae) from North Western Himalayas, India. Annals of Plant Sciences 7.3 (2018) pp. 2096-2100.

d o http://dx.doi.org/10.21746/aps.2018.7.3.1

Source of support: University Grant Commission, New Delhi

Conflict of interest: Nil 